\title{
EFFECT OF DIFFERENT CULTURE TUBE CAPS AND CONCENTRATIONS OF ACTIVATED CHARCOAL AND SUCROSE ON in vitro GROWTH AND BUDDING INDUCTION OF Annona glabra $\mathrm{L}$.
}

\author{
Efeito do tipo de selamento do recipiente de cultura, diferentes concentrações de carvão \\ ativado e sacarose na indução e crescimento de brotações in vitro de Annona glabra $\mathrm{L}$.
}

\author{
José Raniere Ferreira de Santana ${ }^{1}$, Renato Paiva ${ }^{2}$, Ana Valéria de Souza ${ }^{3}$, Lenaldo Muniz de Oliveira ${ }^{4}$
}

\begin{abstract}
The present work evaluated the effects of different types of culture flask seals and varying concentrations of sucrose and activated charcoal on the in vitro induction and growth of buds of Annona glabra L.; an edible fruit-producing species popularly known as "araticum". Nodal segments obtained from A. glabra plants maintained in green houses were surface sterilized and inoculated into a WPM culture medium solidified with $7 \mathrm{~g} \mathrm{~L}^{-1}$ of agar and supplemented with sucrose $(0.00 ; 29.21 ; 58.63$ and 116.84 $\mathrm{mM})$, activated charcoal $\left(0.0\right.$ and $\left.2.0 \mathrm{~g} \mathrm{~L}^{-1}\right)$, and $250 \mathrm{mg} \mathrm{L}^{-1}$ benomyl. In addition to the varying concentrations of sucrose and activated charcoal, we evaluated the efficiency of two types of test tube seals: PVC film, and cotton plugs. All possible combinations of caps and nutrient media were tested with 4 repetitions with 5 tubes each, evaluating the number of buds, the percentage of explant responses, the number of expanded leaves per bud, the length of the largest leaves, leaf abscission, and the length and dry weight of the buds. The type of seal influenced organogenesis in nodal segments of A. glabra, and no bud induction was observed in the absence of sucrose. The largest number of expanded leaves were obtained when $58.42 \mathrm{mM}$ of sucrose was used in tubes sealed with cotton plugs, and leaf abscission was halved in the presence of activated charcoal. The greatest bud length and dry weight were obtained in tubes sealed with cotton plugs and in the presence of activated charcoal.
\end{abstract}

Index terms: Annonaceae, cotton plugs, leaf abscission.

\section{RESUMO}

Este trabalho foi realizado com o objetivo de avaliar o efeito do tipo de selamento do recipiente de cultura e diferentes concentrações de sacarose e carvão ativado na indução e crescimento de brotações in vitro de Annona glabra L.; espécie frutífera conhecida popularmente como araticum. Segmentos nodais obtidos de plantas de A. glabra mantidas em casa de vegetação, após o processo de assepsia, foram inoculados em meio de cultura WPM com $7 \mathrm{~g} \mathrm{~L}^{-1}$ de agar e sacarose $(0,00 ; 29,21 ; 58,63$ e $116,84 \mathrm{mM})$ combinado com carvão ativado $\left(0,0\right.$ e $\left.2,0 \mathrm{~g} \mathrm{~L}^{-1}\right)$ e $250 \mathrm{mg} \mathrm{L}^{-1}$ de benomil. Avaliaram-se dois tipos de selamento nos tubos de ensaio: tampa com película de PVC e tampão de algodão. O experimento foi instalado em DIC em arranjo fatorial 4x2x2, com 4 repetições/ 5 tubos por parcela. Avaliou-se o número brotações, a porcentagem de explantes responsivos, o número de folhas expandidas por brotação, o comprimento da maior folha, a abscisão foliar, o comprimento e a matéria seca das brotações. O tipo de selamento influenciou a organogênese em segmentos nodais de A. glabra. Contudo, não houve indução de brotações na ausência de sacarose. $\mathrm{O}$ maior número de folhas expandidas foi obtido quando utilizou-se $58,42 \mathrm{mM}$ de sacarose em tubos selados com tampão de algodão e a abscisão foliar foi reduzida à metade na presença do carvão ativado. Maiores comprimentos e maiores pesos da matéria seca das brotações foram obtidos em tubos selados com tampão de algodão, também na presença de carvão ativado.

Termos para indexação: Annonaceae, tampão de algodão, abscisão foliar.

(Received in september 2, 2010 and approved in november 11, 2010)

\section{INTRODUCTION}

The family Annonaceae comprises more than 100 genera and 2,000 species distributed within tropical regions, with only a few genera occurring in temperate zones. The species Annona glabra occurs in tropical Africa and in the tropical Americas and can be found in the states of MT, GO, MG, RS and SP in Brazil, where it is popularly known as "araticum", "araticum do brejo", "araticum bravo", "araticum de mangue", "araticum d'water" or "araticum da lagoa". Its fruits are eaten by the native fauna as well as by humans, and the bark, stem, leaves and fruits have therapeutic properties and are widely used in folk remedies (PADMAJA et al., 1995; MANICA, 2003; ZHANG et al., 2004; SIEBRA et al., 2009).

\footnotetext{
1Universidade Estadual de Feira de Santana/UEFS - Departamento de Biologia/DBIO - Laboratório de Cultura de Tecidos - Unidade Experimental Horto Florestal - Avenida Presidente Dutra - S/N - Santa Mônica - 44055-000 - Feira de Santana, BA - raniere@uefs.br

'Universidade Federal de Lavras/UFLA - Departamento de Biologia/DBI - 37200-000 - Lavras, MG

${ }^{3}$ Empresa Brasileira de Pesquisa Agropecuária/Embrapa - Semiárido CPATSA - Petrolina, PE

${ }^{4}$ Universidade Estadual de Feira de Santana/UEFS - Departamento de Biologia/DBIO - Feira de Santana, BA
} 
According to Manica (2003), the use of biotechnology has resulted in significant advances in research programs directed towards the genetic improvement and cultivation of native fruits. These techniques are still very incipient in relation to the anonnas, however, and micropropagation has only been used in the production of plantlets of "atemoia" (Custard Apple), cherimoya, and graviola. There are as yet no reports of active research with A. glabra that could aid the production of planting stock on a commercial scale, and it is important to better understand the factors controlling morphogenetic processes during in vitro culturing of this species.

Among the numerous techniques used to optimize micropropagation protocols for woody species, stimulation of photoautotrophy is highly beneficial as it results in better growth and development of the plants when they are transferred from an in vitro to an in vivo environment (KOZAI, 1991; BUDDENDORF-JOOSTEN; WOLTERING, 1996; PAIVA, 2004). Reduction in the concentration of carbohydrates in the culture medium, increasing light intensity, and the elevation of $\mathrm{CO}_{2}$ concentrations in the culture medium by increasing gas exchange and facilitating acclimatization, all aid in producing plants with better control of transpiration (SANTA MARÍA et al., 2000).

In addition to these factors, supplementing the culture medium with activated charcoal has been found to be indispensible for inducing in vitro morphogenesis and rhizogenesis in many woody species (SOUZA; PEREIRA, 2007; THOMAS, 2008). Some authors have reported that the stimulating effects of this compound appear to be due to its irreversible absorption of inhibitory compounds and toxic metabolites produced in vitro by explants, darkening and aerating the culture medium, and the liberation of substances naturally present in activated charcoal that can promote plant growth (GEORGE, 1993; GRATTAPAGLIA; MACHADO, 1998; MOHAMEDYASSEEN, 2001; NOGUEIRA, 2007).

Considering the significant influence of the factors described above on the production of planting stock of woody species under in vitro conditions and the lack of studies of this nature with A. glabra, the present work evaluated the effects of the types of culture flask seals and different concentrations of activated charcoal and sucrose on the in vitro induction and bud growth.

\section{MATERIALS AND METHODS}

The experiments described here were carried out in the Plant Tissue Culture Laboratory of the Plant
Physiology Department at the Universidade Federal de Lavras, in Lavras, Minas Gerais State, Brazil. Nodal segments for in vitro culture were obtained from lateral sections of the semi-lignified stems of A. glabra plants that had been maintained in green houses (without temperature controls). The leaves and the nodal segments were rinsed in running water for 20 minutes and then washed with neutral detergent. The material was then sectioned in a laminar-flow chamber into 10-15 mm length, each with a single bud, and surface-sterilized by immersion in $70 \%$ alcohol (v/v) for 1 minute, followed by immersion for 15 minutes in sodium hypochlorite (1\% active chlorine) with a few drops of detergent.

The surface-sterilized nodal segments were then washed five times in sterile distilled water and inoculated into test tubes $(25 \times 150 \mathrm{~mm})$ containing WPM culture medium (Lloyd; McCown, 1980) solidified with $7 \mathrm{~g} \mathrm{~L}^{-1}$ of agar and supplemented with sucrose $(0.00 ; 29.21 ; 58.42$ and 116.84 $\mathrm{mM})$ and activated charcoal $\left(0.0\right.$ and $\left.2.0 \mathrm{~g} \mathrm{~L}^{-1}\right)$ and $250 \mathrm{mg} \mathrm{L}^{-1}$ benomyl; the $\mathrm{pH}$ of the culture medium had been adjusted to 5.7 before autoclaving at $121^{\circ} \mathrm{C}$ for 15 minutes.

One nodal segment was inoculated intoeach tube under sterile conditions and subsequently maintained in a growth chamber at $25 \pm 3^{\circ} \mathrm{C}$ with a $16 \mathrm{~h}$ photoperiod at photosynthetically active radiation levels of $45-56 \mu \mathrm{mol} \mathrm{m}^{-2} \mathrm{~s}^{-1}$ provided by florescent lamps.

In addition to the varying concentrations of sucrose and activated charcoal, we evaluated two types of seals for the test tubes: a PVC film (together with a common plastic cap) or cotton plugs. $10 \mathrm{~mL}$ of culture medium was used in test tubes sealed with the PVC film, and $20 \mathrm{~mL}$ in the tubes closed with cotton plugs - as preliminary experiments had shown that media evaporation was highest from tubes closed with cotton plugs. The activated charcoal was added before boiling the agar, and the $\mathrm{pH}$ was then adjusted to 5.7. All of the tubes were sealed with plastic caps before autoclaving, but these were replaced by sterile cotton plugs after inoculation with the nodal segments as appropriate.

All possible combinations of sucrose and charcoal concentrations and seal types were made, with 4 repetitions of 5 tubes. Forty-two days after inoculation we evaluated the number of buds, the percentage of responding explants, the number of expanded leaves per bud, the length of the largest leaves, leaf abscission (number of abscised leaves per bud), and the length and dry weight of the buds.

\section{RESULTSAND DISCUSSION}

The type of seal significantly influenced organogenesis in nodal segments of A. glabra. The largest 
number of buds ( 0.57 per explant) and the largest percentage of explant responses $(56.25 \%)$ were obtained when the tubes were sealed with cotton plugs (Table 1). These results corroborate with those reported by Bandeira et al. (2007), who also obtained the largest number of buds of Thymus vulgaris L. in flasks sealed with cotton plugs, but differed from the results of Mohamed and Alsadon (2010) who evaluated the influence of ventilation and different sucrose concentrations on the in vitro growth of potato plantlets and obtained the largest number of buds in non-ventilated flasks.

When the influence of activated charcoal and different concentrations of sucrose were evaluated, it was observed that: in the absence of sucrose there was no bud induction in the nodal segments; the largest number of buds were obtained in the absence of activated charcoal among all of the sucrose concentrations tested, and; high concentrations of sucrose $(116.86 \mathrm{mM})$ combined with activated charcoal $\left(2 \mathrm{~g} \mathrm{~L}^{-1}\right)$ significantly reduced organogenesis (Table 2). These results were similar to those reported by Rodrigues et al. (2006) and Bandeira et al. (2007) in their studies of in vitro vegetative propagation of apples and Thymus vulgaris, respectively.

The presence of a carbon source in the culture medium during in vitro culture is fundamental to the propagation of woody species, for in addition to acting as energy sources and osmotic regulators, the carbohydrates can influence growth and tissue differentiation and participate in the regulation of genetic expression (DOBRÁNSZKI; SILVA, 2010). According to Leite and Fortes (2000), high concentrations of sucrose in the culture medium can negatively affect the in vitro development of the aerial portion of plants as it can diminish their photoautotrophic capacity. Wainwright and Scarce (1987) noted that low concentrations of sucrose in the culture medium can stimulate a beneficial change in the growth of plantlets in their transition from heterotrophy to autotrophy, thus facilitating an increase in their photosynthetic capacity. But Santana et al. (2008) observed that, in addition to sucrose, aeration of the culture vessels can also stimulate autotrophy in in vitro cultivated plants of A. glabra.

Combinations of different sucrose concentrations with different types of seals produced positive effects in terms of bud induction. When the tubes were sealed with cotton plugs with concentrations of 29.21 and $58.42 \mathrm{mM}$ sucrose, bud induction was significantly superior to that seen using plastic caps with PVC film. On the other hand, an inhibiting effect was seen with the highest concentration of sucrose $(116.86 \mathrm{mM})$ in bud induction when cotton plugs were used (Table 3). Bandeira et al. (2007) observed a similar effect when they evaluated the effects of different vessel seals with different concentrations of sucrose on the in vitro multiplication $T$. vulgaris.

Table 1 - Average values for the number of buds per explant and percentage of explant responses of nodal segments of Annona glabra L. as a function of the type of flask seal used.

\begin{tabular}{ccc}
\hline Type of seal & Number of buds & Explant responses $(\%)$ \\
\hline Cotton plugs & $0.57 \mathrm{a}^{\mathrm{z}}$ & $56.25 \mathrm{a}$ \\
Plastic caps with PVC film & $0.41 \mathrm{~b}$ & $41.25 \mathrm{~b}$ \\
\hline
\end{tabular}

${ }^{z}$ - Averages followed by the same letter in each column do not differ significantly at a $5 \%$ level of probability by the Tukey test.

Table 2 - Average results for the number of buds per explant and percentage of explant responses in nodal segments of Annona glabra L. as a function of sucrose and activated charcoal concentrations.

\begin{tabular}{|c|c|c|c|c|c|}
\hline \multirow{2}{*}{$\begin{array}{c}\text { Activated } \\
\text { charcoal }\left(\mathrm{g} \mathrm{L}^{-1}\right)\end{array}$} & \multicolumn{4}{|c|}{ Sucrose (mM) } & \multirow[t]{2}{*}{ Average } \\
\hline & 0.00 & 29.21 & 58.42 & 116.86 & \\
\hline \multicolumn{6}{|c|}{ Number of buds per explant } \\
\hline 0.0 & $0.00 \mathrm{a}^{\mathrm{z}}$ & $0.65 \mathrm{a}$ & $0.70 \mathrm{a}$ & $0.82 \mathrm{a}$ & $0.54 \mathrm{a}$ \\
\hline 2.0 & $0.00 \mathrm{a}$ & $0.45 \mathrm{a}$ & $0.72 \mathrm{a}$ & $0.57 \mathrm{~b}$ & $0.43 \mathrm{~b}$ \\
\hline \multicolumn{6}{|c|}{ Explant responses $(\%)$} \\
\hline 0.0 & $0.0 \mathrm{a}$ & $65.0 \mathrm{a}$ & $70.0 \mathrm{a}$ & $82.5 \mathrm{a}$ & $54.37 \mathrm{a}$ \\
\hline 2.0 & $0.0 \mathrm{a}$ & $45.0 \mathrm{a}$ & $72.0 \mathrm{a}$ & $57.5 \mathrm{~b}$ & $43.12 \mathrm{~b}$ \\
\hline
\end{tabular}

${ }^{z}$ - Averages followed by the same letter in each column do not differ significantly at a $5 \%$ level of probability by the Tukey test.

Ciênc. agrotec., Lavras, v. 35, n. 5, p. 916-923, set./out., 2011 
Table 3 - Average results for the number of buds per explant, percentage of explant responses, number of expanded leaves per bud, and length of the largest leaves in nodal segments of Annona glabra L. as a function of sucrose concentrations and seal types.

\begin{tabular}{|c|c|c|c|c|c|}
\hline \multirow{2}{*}{$\begin{array}{c}\text { Types of } \\
\text { Seals }\end{array}$} & \multicolumn{4}{|c|}{ Sucrose $(\mathrm{mM})$} & \multirow[t]{2}{*}{ Average } \\
\hline & 0.00 & 29.21 & 58.42 & 116.86 & \\
\hline \multicolumn{6}{|c|}{ Number of buds per explant } \\
\hline Cotton plugs & $0.00 \mathrm{a}^{\mathrm{z}}$ & $0.72 \mathrm{a}$ & $0.85 \mathrm{a}$ & $0.70 \mathrm{a}$ & $0.56 \mathrm{a}$ \\
\hline Caps with PVC film & $0.00 \mathrm{a}$ & $0.37 \mathrm{~b}$ & $0.57 \mathrm{~b}$ & $0.70 \mathrm{a}$ & $0.41 \mathrm{~b}$ \\
\hline \multicolumn{6}{|c|}{ Explant responses $(\%)$} \\
\hline Cotton plugs & $0.00 \mathrm{a}$ & $72.50 \mathrm{a}$ & $82.00 \mathrm{a}$ & $70.00 \mathrm{a}$ & $56.25 \mathrm{a}$ \\
\hline Caps with PVC film & $0.00 \mathrm{a}$ & $37.50 \mathrm{~b}$ & $57.50 \mathrm{~b}$ & $70.00 \mathrm{a}$ & $41.25 \mathrm{~b}$ \\
\hline \multicolumn{6}{|c|}{ Number of expanded leaves per bud } \\
\hline Cotton plugs & $0.00 \mathrm{a}$ & $1.94 \mathrm{a}$ & $3.22 \mathrm{a}$ & $1.90 \mathrm{a}$ & $1.76 \mathrm{a}$ \\
\hline Caps with PVC film & $0.00 \mathrm{a}$ & $0.42 \mathrm{~b}$ & $2.27 \mathrm{~b}$ & $2.37 \mathrm{a}$ & $1.26 \mathrm{~b}$ \\
\hline \multicolumn{6}{|c|}{ Length of the largest leaves (mm) } \\
\hline Cotton plugs & $0.00 \mathrm{a}$ & $20.64 \mathrm{a}$ & $17.96 \mathrm{a}$ & $12.57 \mathrm{a}$ & $12.79 \mathrm{a}$ \\
\hline Caps with PVC film & $0.00 \mathrm{a}$ & $3.01 \mathrm{~b}$ & $8.91 \mathrm{~b}$ & $14.78 \mathrm{a}$ & $6.67 \mathrm{~b}$ \\
\hline
\end{tabular}

${ }^{\mathrm{z}}$ - Averages followed by the same letter in each column do not differ significantly at a $5 \%$ level of probability by the Tukey test.

The percentage of responsive explants followed the same pattern as the number of expanded leaves per plant. When PVC seals were used, the largest number of buds (0.7/explant) were obtained with the highest concentrations of sucrose, and when cotton seals were used the largest number of buds (0.85/explant) were observed in the presence of 58.42 $\mathrm{mM}$ sucrose (Table 3 ). It is possible that the highest concentration of sucrose led to a significant increase in the osmotic potential of the medium - and with less free water available, transpiration and bud growth were reduced.

The largest number of expanded leaf buds on sections of $A$. glabra cultivated in vitro $(3.22 / \mathrm{bud})$ were obtained when $58.42 \mathrm{mM}$ of sucrose was used in tubes sealed with cotton plugs. The largest leaves were significantly longer when the tubes were sealed with the cotton plugs; the use of cotton plugs with $29.21 \mathrm{mM}$ sucrose produced leaves that were six times longer than those produced in tubes sealed with PVC film (Table 3). These results with better aerated tubes were similar to those reported for A. squamosa L. (ARMSTRONG et al., 1997; ZOBAYED et al., 2002) and A. muricata L. (ZOBAYED et al., 2002) using forced ventilation. Mohamed and Alsadon (2010) likewise obtained the largest leaves with in vitro potato plantlets cultivated in ventilated flasks.
Our studies demonstrated a reduction by half of leaf abscission in the presence of activated charcoal, shifting from 0.18 fallen leaves per bud to 0.09 - but leaf fall was reduced only when cotton plugs were used to seal the culture vessels (Tables 4 and 5). These results were similar to those obtained with forced ventilation with the species A. squamosa and A. muricata by Zobayed et al. (2002), or to those obtained in the presence of compounds that inhibit the effects of ethylene. These inhibitory compounds are capable of reducing $95 \%$ of the leaf abscission in in vitro cultures of $A$. squamosa for a period of 30 days (LEMOS; BLAKE, 1996).

Cotton plug seals were found to be best option for in vitro cultivation of A. glabra as they allowed the production of the largest buds when activated charcoal was included in the culture medium. Different results were seen with different concentrations of sucrose, however, with the longest buds being obtained in the presence of $58.42 \mathrm{mM}$ sucrose $(38.50 \mathrm{~mm})$; when sucrose concentrations in the culture medium were less (29.21 $\mathrm{mM}$ ), the buds averaged 17.35 and $20.25 \mathrm{~mm}$ in length in the presence and in the absence of activated charcoal respectively.

These differences indicate there was a stimulation of growth when gas exchange (transpiration) was facilitated by the cotton plugs. This benefit of increased aeration of the culture vessels is lost, however, when the 
sucrose concentration in the culture medium is high (116.86 $\mathrm{mM}$ ), and this loss is even more accentuated in the absence of activated charcoal. The opposite occurs when common plastic (PVC) caps are used, with the presence of the activated charcoal in the culture medium having no measurable effect and bud growth increasing steadily as the levels of carbohydrates increased. With the PVC seals, the largest buds were obtained with the highest sucrose concentration $(116.86 \mathrm{mM})$ - for the stimulating effect of activated charcoal on growth was only seen in tubes with cotton seals (Table 6).

According to Fridborg et al. (1978), activated charcoal is a useful coadjutant for bud growth due to its capacity to bind excessive concentrations of plant growth regulators and toxic compounds that could otherwise inhibit morphogenesis. Pan and Staden (1998) reported that activated charcoal removed inhibitory compounds from the culture medium (such as 5-hydroxymethyl furfural that is produced from sucrose during autoclaving), but McCown (1988) noted that the effects of activated charcoal on the development of in vitro plant cultures depended on the chemical composition of the culture medium and on the plant's genotype.

The use of activated charcoal in studies of in vitro reproduction and rooting in Acacia mearnsii De Wild. showed it to be efficient for promoting rooting and normal development of the aerial part of the plant, as well as preventing chlorosis of the leaves (QUORIN et al., 2001). Srivastava and Chaturvedi (2008) likewise noted the necessity of using activated charcoal for culturing the anthers of Annona squamosa, as it impeded the liberation of phenolic compounds into the culture medium.

Table 4 - Average results for leaf abscission (number of leaves per bud) in nodal segments of Annona glabra L. as a function of varying concentrations of sucrose and activated charcoal.

\begin{tabular}{cccccc}
\hline \multirow{2}{*}{$\begin{array}{c}\text { Activated } \\
\text { charcoal }\left(\mathrm{g} . \mathrm{L}^{-1}\right)\end{array}$} & \multicolumn{4}{c}{ Sucrose $(\mathrm{mM})$} & \multirow{2}{*}{ Average } \\
\cline { 2 - 4 } 0.0 & 0.00 & 29.21 & 58.42 & 116.86 & \\
\hline 2.0 & $0.00 \mathrm{a}^{\mathrm{z}}$ & $0.10 \mathrm{a}$ & $0.28 \mathrm{a}$ & $0.38 \mathrm{a}$ & $0.18 \mathrm{a}$ \\
\hline
\end{tabular}

${ }^{z}$ - Averages followed by the same letter in each column do not differ significantly at a 5\% level of probability by the Tukey test.

Table 5 - Average results of leaf abscission (number of leaves per bud) in nodal segments of Annona glabra L. as a function of different concentrations of sucrose and seal types.

\begin{tabular}{cccccc}
\hline Seal Type & \multicolumn{4}{c}{ Sucrose $(\mathrm{mM})$} & \multirow{2}{*}{ Average } \\
\cline { 2 - 5 } & 0.00 & 29.21 & 58.42 & 116.86 & $0.02 \mathrm{~b}$ \\
\hline Cotton plugs & $0.00 \mathrm{a}^{\mathrm{z}}$ & $0.00 \mathrm{~b}$ & $0.03 \mathrm{~b}$ & $0.05 \mathrm{~b}$ & $0.26 \mathrm{a}$ \\
\hline
\end{tabular}

${ }^{z}$ - Averages followed by the same letter in each column do not differ significantly at a $5 \%$ level of probability by the Tukey test.

Table 6 - Average results for bud length ( $\mathrm{mm}$ ) of nodal segment of Annona glabra L. at varying sucrose levels, with or without activated charcoal, and using different vessel caps.

\begin{tabular}{|c|c|c|c|c|c|}
\hline \multirow[t]{2}{*}{ Seal Types } & \multicolumn{4}{|c|}{ Sucrose $(\mathrm{mM})$} & \multirow[t]{2}{*}{ Average } \\
\hline & 0.00 & 29.21 & 58.42 & 116.86 & \\
\hline \multicolumn{6}{|c|}{$0.0 \mathrm{~g} \mathrm{~L}^{-1}$ of activated charcoal } \\
\hline Caps with PVC film & $0.00 \mathrm{a}$ & $4.30 \mathrm{~b}$ & $16.50 \mathrm{a}$ & $21.25 \mathrm{a}$ & $10.51 \mathrm{a}$ \\
\hline Cotton plugs & $0.00 \mathrm{a}$ & $17.35 \mathrm{a}$ & $18.00 \mathrm{a}$ & $12.75 \mathrm{~b}$ & $12.02 \mathrm{a}$ \\
\hline \multicolumn{6}{|c|}{$2.0 \mathrm{~g} \mathrm{~L}^{-1}$ of activated charcoal } \\
\hline Caps with PVC film & $0.00 \mathrm{a}$ & $2.00 \mathrm{~b}$ & $9.50 \mathrm{~b}$ & $23.75 \mathrm{a}$ & $8.81 \mathrm{~b}$ \\
\hline Cotton plugs & $0.00 \mathrm{a}$ & $20.25 \mathrm{a}$ & $38.50 \mathrm{a}$ & $26.75 \mathrm{a}$ & $21.37 \mathrm{a}$ \\
\hline
\end{tabular}

Ciênc. agrotec., Lavras, v. 35, n. 5, p. 916-923, set./out., 2011 
The dry weight of the buds also varied with sucrose concentrations, the presence or absence of activated charcoal in the culture medium, the type of seal and followed the same tendencies as described above for bud length. However, the positive effects of better gas exchange through the cotton plugs were neutralized in the highest concentration of sucrose, principally in the absence of activated charcoal (Table 7). Similar results were reported by Mohamed and Alsadon (2010), who observed that increasing the concentration of sucrose from 29.21 to $87.94 \mathrm{mM}$ favored fresh weight gains in potato plantlets that were cultivated in non-ventilated flasks.

The combination of the cotton seal with activated charcoal and an intermediary sucrose concentration (58.42 $\mathrm{mM}$ ) yielded buds with greatest dry weight $(23.12 \mathrm{mg})$ (Table 7). Independent of the concentrations of sucrose used in the culture medium with added activated charcoal, the cotton plug seals promoted better weight gains than the use of PVC caps.

High concentrations of sucrose can reduce the water potential of the culture medium and depress plant transpiration, with consequent reductions of nutrient absorption. Improvements in gas exchange, on the other hand, will facilitate transpiration and increase the absorption of nutrients from the culture medium - resulting in better growth and development of the in vitro explants. As such, the reduction in bud growth of A. glabra observed in culture media with the highest sucrose concentration may have been the result of a reduction in their transpiration, even when the type of seal did not restrict gas exchange.

Mosaleeyanon et al. (2004) likewise observed that high concentrations of sucrose negatively affected the fresh and dry weight of Samanea saman Merr buds, and Maldaner et al. (2007) reported better responses in terms of the number and length of the buds of Pfaffia glomerata (Spreng.) Pedersen at sucrose concentration of $87.64 \mathrm{mM}$.

The differences between the two sealing systems evaluated in the present study are notable, and under the experimental conditions tested here the cotton caps yielded the best responses. Deccetti et al. (2008) evaluated the effects of different vessel sealing systems in in vitro studies of A. glabra and observed that natural ventilation combined with photosynthetically active irradiance values of $300 \mu \mathrm{mol} . \mathrm{m}^{2} \mathrm{~s}^{1}$ increased the capacity of the plantlets to control water loss - which appears to be extremely important in avoiding plant desiccation during acclimatization. These authors also reported that plants of this species cultivated under natural conditions of ventilation with high $\mathrm{CO}_{2}$ availability had the same stomatal frequency as plants growing under natural conditions.

A number of studies designed to increase in vitro gas exchange have been successful at facilitating plant acclimatization. Workers have obtained positive results using techniques such as enriching in vitro $\mathrm{CO}_{2}$ concentrations and using culture media with different concentrations of sucrose (MARTIN, 2004; MOSALEEYANON et al., 2004). The present study with $A$. glabra demonstrated, however, that the benefits obtained by using cotton plugs to seal the culture flasks are similar to those obtained by using forced ventilation or compounds that inhibit the action of ethylene.

In their revision of tissue culturing with different species of Annona sp., Rasai et al. (1995) cited the importance of inducing autotrophy to facilitate acclimatization, and noted the positive effects obtained by reducing sucrose concentrations in the culture medium. The results presented here with A. glabra indicate that improving the aeration of the culture vessel reduces the relative humidity and increases gas exchange.

Table 7 - Average results for the dry weight of the buds (mg) of nodal segments of Annona glabra $\mathrm{L}$. at varying sucrose levels, with or without activated charcoal and using different vessel caps.

\begin{tabular}{|c|c|c|c|c|c|}
\hline \multirow{2}{*}{ Seal Type } & \multicolumn{4}{|c|}{ Sucrose $(\mathrm{mM})$} & \multirow{2}{*}{ Average } \\
\hline & 0.00 & 29.21 & 58.42 & 116.86 & \\
\hline \multicolumn{6}{|c|}{$0.0 \mathrm{~g} . \mathrm{L}^{-1}$ of activated charcoal } \\
\hline Caps with PVC film & $0.00 \mathrm{a}$ & $0.56 \mathrm{~b}$ & $3.80 \mathrm{~b}$ & $8.95 \mathrm{a}$ & $3.32 \mathrm{a}$ \\
\hline Cotton plugs & $0.00 \mathrm{a}$ & $10.30 \mathrm{a}$ & $8.24 \mathrm{a}$ & $7.80 \mathrm{a}$ & $6.58 \mathrm{a}$ \\
\hline \multicolumn{6}{|c|}{$2.0 \mathrm{~g} \mathrm{~L}^{-1}$ of activated charcoal } \\
\hline Caps with PVC film & $0.00 \mathrm{a}$ & $0.62 \mathrm{~b}$ & $0.96 \mathrm{~b}$ & $13.60 \mathrm{a}$ & $3.80 \mathrm{~b}$ \\
\hline Cotton plugs & $0.00 \mathrm{a}$ & $9.98 \mathrm{a}$ & $23.12 \mathrm{a}$ & $17.66 \mathrm{a}$ & $12.69 \mathrm{a}$ \\
\hline
\end{tabular}

Ciênc. agrotec., Lavras, v. 35, n. 5, p. 916-923, set./out., 2011 
Santana et al. (2008) examined the effects of different types of seal and sucrose concentrations on the development of the root system of A. glabra, and concluded that the seal type most influenced root growth; sealing the flasks with plastic caps (but without PVC film), or with cotton plugs, allowed gas exchange and facilitated adventitious root induction. Secondary roots were only seen in plants growing with sufficient aeration.

The present work performed with A. glabra was designed to contribute to efforts to micropropagate Annonaceae on a commercial scale and to present accessible and economically viable solutions to the problem of precocious leaf abscission (the principal obstacle for the in vitro cultivation of various species of this family).

\section{CONCLUSION}

Our evaluations of the effects of varying sucrose concentrations, the addition of activated charcoal, and different types of culture vessel seals on the in vitro organogenesis of Annona glabra all indicate that aeration of the culture vessels is one of the most important factors contributing to the production of viable acclimatized plantlets. The use of cotton stoppers allows gas exchange and resulted in significant increases in bud growth. The presence of sucrose in the culture medium is essential for bud organogenesis, and the use of activated charcoal appears to be a potentially very interesting complement to the use of a cotton seal in the in vitro production of planting stocks of A. glabra.

\section{REFERENCES}

ARMSTRONG, J. et al. A humidity-induced convective through flow ventilation systems benefits Annona squamosa L. explants and coconut calloid. Annals of Botany, London, v.79, n.1, p.31-49, 1997.

BANDEIRA, J.M.; LIMA, C.S.M.; RUBINI, S. Diferentes tipos de vedações dos frascos e concentrações de sacarose na micropropagação de Thymus vulgaris $\mathrm{L}$. Revista Brasileira de Biociências, Porto Alegre, v.5, n.2, p.472-474, 2007. Suplemento.

\section{BUDDENDORF-JOOSTEN,J.M.C.; WOLTERINGE.J.}

Controlling the gaseous composition in vitro- description of a flow system and effects of the different gaseous components on in vitro growth of potato plantlets. Scientia Horticulturae, Wageningen, v.65, n.1, p.11-23, 1996.

DECCETTI, S.F. et al. Effect of the culture environment on stomatal features, epidermal cells and water loss of micropropagated Annona glabra L. plants. Scientia Horticulturae, Amsterdam, v.117, p.341-344, 2008.

DOBRÁNSZKI, J.; SILVA, J.A.T. Micropropagation of apple: a review. Scientia Horticulturae, Amsterdam, v.119, p.141-146, 2010.

FRIDBORG, G. et al. The effects of activated charcoal on tissue cultures: adsorption of metabolites, inhibition of morphogenesis. Physiologia Plantarum, Copenhagen, v.43, n.2, p.104-106, 1978.

GEORGE, E.F. Plant propagation by tissue culture: part 1, The technology. 2.ed. Edington: Exegetics, 1993. 574p.

KOZAI, T. Micropropagation under photoautotrophic conditions. In: DEBERGH, P.; ZIMMERMAN, R. (Eds.). Micropropagation, technology and application. Dordrecht: Kluwer Academic, 1991. p.447-469.

LEITE, G.B.; FORTES, G.R.L. Efeitos de concentrações de sacarose no meio de cultura e de intensidade luminosa no enraizamento in vitro do porta-enxerto de pereira $\mathrm{Oh}$ X F97. Ciência e Agrotecnologia, Lavras, v.24, n.2, p.353-357, mar./abr. 2000.

LEMOS, E.E.P.; BLAKE, J. Control of leaf abscission in nodal cultures of Annona squamosa $\mathrm{L}$. Journal of Horticultural Science, Ashford, v.71, n.5, p.721-728, 1996.

LLOYD, G.; MCCOWN, B. Use of microculture for production and improvement of Rhododendron spp. HortScience, Alexandria, v.15, p.415, 1980. Abstract 321.

MALDANER, J.; NICOLOSO, F.T.; SANTOS, F.S. Crescimento de plântulas de Pfaffia glomerata (Spreng.) Pedersen cultivadas in vitro sob dois níveis de nitrogênio e sacarose, durante seis subculturas sucessivas e aclimatização. Ciência Rural, Santa Maria, v.37, n.1, p.133-140, jan./fev. 2007.

MANICA, I. Taxonomia, morfologia e anatomia. In: . Frutas anonáceas: ata ou pinha, atemólia, cherimólia e graviola: tecnologia de produção, pós-colheita e mercado. Porto Alegre: Cinco Continentes, 2003. p.23-64.

MARTIN, K.P. In vitro propagation of the herbal spice Eryngium foetidum L. on sucrose-added and sucrosefree medium without growth regulators and $\mathrm{CO}^{2}$ enrichment. Scientia Horticulturae, Amsterdam, v.102, p.277-282, 2004. 
MCCOWN, B.H. Adventitious rooting of tissue cultured plants. In: DAVIS, T.D.; HAISSIG, B.E.; SANKHLA, N. (Eds.). Adventitious root formation in cuttings. Portland: Dioscorides, 1988. v.2, p.289-302.

MOHAMED, M.A.H.; ALSADON, A.A. Influence of ventilation and sucrose on growth and leaf anatomy of micropropagated potato plantlets. Scientia Horticulturae, Amsterdam, v.123, p.295300, 2010.

MOHAMED-YASSEEN, Y. Influence of agar and activated charcoal on uptake of gibberellin and plant morphogenesis in vitro. In Vitro Cellular and

Developmental Biology - Plant, London, v.37, n.2, p.204205, 2001.

MOSALEEYANON, K.; CHA-UM, S.; KIRDMANEE, C. Enhanced growth and photosynthesis of rain tree (Samanea saman Merr.) plantlets in vitro under a $\mathrm{CO}^{2}$-enriched condition with decreased sucrose concentrations in the medium. Scientia Horticulturae, Amsterdam, v.103, p.51-63, 2004.

NOGUEIRA, R.C. et al. Calli induction from leaf explants of murici-pequeno (Byrsonima intermedia A. Juss.). Ciência e Agrotecnologia, Lavras, v.31, n.2, p.366-370, Mar./Apr. 2007.

PADMAJA, V. et al. Biological activities of Annona glabra. Journal of Ethnopharmacology, Lausanne, v.48, n.1, p.21-24, 1995.

PAIVA, P.D. de O. et al. In vitro stablisment of strelitzia (Strelitzia reginae Banks.). Ciência e Agrotecnologia, Lavras, v.28, n.5, p.1031-1037, Sep./Oct. 2004.

PAN, M.J.; STADEN, J. van. The use of charcoal in in vitro culture: a review. Plant Growth Regulation, Dordrecht, v.26, p.155-163, 1998.

QUORIN, M. et al. Multiplication of juvenile black wattle by micro cuttings. Plant Cell, Tissue and Organ Culture, Dordrecht, v.66, p.199-205, 2001.

RASAI, S.; GEORGE, A.P.; KANTHARAJAH, S. Tissue culture of Annona spp. (cherimoya, atemoya, supar apple and soursop): a review. Scientia Horticulturae, Amsterdam, v.62, n.1/2, p.1-14, 1995.
RODRIGUES, M.M.; MELO, M.D.; ALOUFA, A.A.I. Propagação vegetativa in vitro e análise estrutural de macieira. Pesquisa Agropecuária Brasileira, Brasília, v.41, n.1, p.171-173, jan. 2006.

SANTA MARÍA, J.M. et al. Ventilation of culture vessels: II., increased water movement rather than reduced concentration of ethylene and $\mathrm{CO}_{2}$ is responsible for improve growth and development of Delphinum in vitro. The Journal of Horticultural Science \& Biotechnology, Ashford, v.75, n.3, p.320-327, May 2000.

SANTANA, J.R.F. et al. Estímulo do comportamento fotoautotrófico durante o enraizamento in vitro de Annona glabra e desenvolvimento do sistema radicular e da parte aérea. Ciência e Agrotecnologia, Lavras, v.32, n.1, p.80-86, jan./fev. 2008.

SIEBRA, C.A. et al. Potencial antiinflamatório de Annona glabra, Annonaceae. Revista Brasileira de

Farmacognosia, São Paulo, v.19, n.1A, p.82-88, 2009.

SOUZA, A.V.; PEREIRA, A.M.S. Enraizamento de plantas cultivadas in vitro. Revista Brasileira de Plantas Medicinais, Botucatu, v.9, n.4, p.103-117, 2007.

SRIVASTAVA, P.; CHATURVEDI, R. In vitro androgenesis in tree species: an update and prospect for further research. Biotechnology Advances, New York, v.26, p.482-491, 2008.

THOMAS, T.D. The role of activated charcoal in plant tissue culture. Biotechnology Advances, New York, v.26, p.618-631, 2008.

WAINWRIGHT, H.; SCARCE, J. Influence of in vitro preconditioning with carbohydrate during the rooting of microcuttings on in vitro establishment. Scientia Horticulturae, Amsterdam, v.38, n.3/4, p.261-267, 1989.

ZHANG, Y. et al. Anticancer effect of two diterpenoid compounds isolated from Annona glabra Linn. Acta Pharmacology, Beijing, v.25, n.7, p.937-942, 2004.

ZOBAYED, S.M.A.; ARMSTRONG, J.; ARMSTRONG, W. Multiple shoot induction and leaf and flower bud abscission of Annona cultures as affected by types of ventilation. Plant Cell, Tissue and Organ Culture, Dordrecht, v.69, n.2, p.155-165, 2002. 